\title{
Konfigurasi Spasial Potensi Kekuatan Gempa Bumi Menggunakan Metode Kriging Semivariogram Anisotropik 3D
}

\author{
Salim*1, Utriweni Mukhaiyar ${ }^{2}$ \\ ${ }^{1}$ Universitas Sembilanbelas November Kolaka \\ ${ }^{2}$ Institut Teknologi Bandung \\ e-mail: ${ }^{1}$ salimmath@usn.ac.id, ${ }^{2}$ utriweni@itb.ac.id
}

\begin{abstract}
Abstrak
Tujuan dilakukan penelitian ini adalah memberikan gambaran spasial lokasi gempa di sekitar observasi yang tidak diketahui dengan metode Ordinary Kriging (OK) melalui semivariogram anisotropik. Data gempa bumi diperoleh dari website IRIS (Incorporated Research Institutions For Seismology), yang pernah terjadi di wilayah Indonesia yaitu di Laut Banda, pada tanggal 31 Januari 2008. Dengan asumsi stasioner, proses pencocokan digunakan dengan model semivariogram Eksponensial. Hasil analisis Ordinary Kriging (OK) melalui semivariogram anisotropik dalam tiga dimensi dari potensi kekuatan gempa bumi diperoleh gambaran spasial bahwa setiap hasil estimasi dipengaruhi perubahan arah dan data observasi di sekitarnya dengan arah sudut $\alpha=45^{\circ}$ dan $\beta=135^{\circ}$. Jika lokasi yang akan diestimasi berada di sekitar data observasi dengan rataan cukup besar, maka hasil estimasi akan mendekati nilai data observasi sebaliknya, jika lokasi yang akan diestimasi berada jauh dari data observasi dengan rataan cukup besar maupun kecil, maka hasil estimasi akan berbeda jauh dengan nilai data observasi.
\end{abstract}

Kata kunci: Model semivariogram, Anisotropik, Ordinary kriging.

\section{PENDAHULUAN}

Indonesia terletak pada pertemuan empat lempeng tektonik yang sangat kompleks dan aktif, yaitu lempeng Eurasia di bagian Utara, lempeng Indo-Australia di bagian Selatan, lempeng Filipina dan Samudera Pasifik di bagian Timur. Lempeng Indo-Australia bergerak relatif ke arah Utara dan menyusup kedalam lempeng Eurasia, sedangkanlempeng Pasifik bergerak relatif ke arah Barat. Pergerakan relatif dari lempeng tektonik tersebut menimbulkan terjadinya sesar-sesar regional yang selanjutnya dapat berkembang menjadi daerah pusat sumber gempa bumi.

Gempa bumi merupakan fenomena atau kejadian yang saling berkaitan. Salah satunya, kejadian gempa bumi di beberapa lokasi di Indonesia yang merupakan kumpulan kejadian saling berkaitan yang menunjukkan suatu pola seperti musiman atau kenderungan baik kecenderungan naik maupun turun. Kumpulan kejadian gempa bumi ini merupakan salah satu proses stokastik, yaitu koleksi/barisan peubah acak dengan indeks parameter tertentu. Jika indeks parameter barisan peubah acak tersebut waktu, maka proses stokastik dapat dianalisis menggunakan deret waktu (time series). Jika indeks parameternya lokasi, maka proses stokastik dianalisis menggunakan analisis spasial (spatial analysis). Indeks parameter yang berupa lokasi dan waktu sekaligus dapat dianalisis dengan gabungan antara analisis deret waktu dan lokasi (space time analysis).

Pemodelan spasial memuat informasi tentang hubungan antara observasi di beberapa lokasi yang berbeda. Alat untuk menggukur kebergantungan antar observasi yang didasarkan pada perbedaan jarak tertentu adalah variogram. Ada beberapa model variogram yang sering digunakan, diantaranya: Spherikal, Eksponensial, Gauss, dan Efek Lubang. Variogram 
Spherikal dapat diterapkan pada data kadar emas di Borneo (Faisal, 2004), variogram Eksponensial dapat diterapkan pada data kandungan gas di Barbour Virginia Barat (Hohn, 1999) dan variogram Efek Lubang dapat diterapkan pada data kandungan besi di Lorraine, Perancis (David, 1977). Model variogram tersebut diperlukan dalam membangun model yang dapat menginterpolasi atau memprediksi variabel di lokasi sekitar observasi (terregional) yang belum diketahui. Metode interpolasi atau prediksi variabel terregional tersebut dinamakan metode kriging (Sari, 2009). Dalam kasus ini, akan diterapkan pemodelan spasial melalui Metode Ordinary Kriging terhadap besarnya kekuatan gempa di salah satu kawasan di Indonesia melalui semivariogram anisotropik tiga dimensi yaitu di lokasi Laut Banda Maluku.

.Tujuan dari penelitian ini adalah untuk menentukan model semivariogram eksperimental yang sesuai, dan memberikan konfigurasi spasial dari potensi gempa di lokasi sekitar observasi yang tidak diketahui. Model semivariogram tersebut digunakan dalam metode kriging melalui semivariogram anisotropik tiga dimensi.

Data spasial adalah data tentang suatu wilayah yang memiliki struktur data dan format tertentu yang memiliki referensi geografis yang benar, disajikan dalam bentuk data grafis dan atribut. Data spasial dapat berupa peta maupun citra penginderaan jauh. Informasi ini menjadi sumber tentang analisis yang berkaitan dengan lokasi. Misalkan $\left\{M(\mathbf{s}): \mathbf{s} \in \mathbb{R}^{3}\right\}$ koleksi peubah acak dengan $M(\mathbf{s})=\left\{M\left(\mathbf{s}_{1}\right), M\left(\mathbf{s}_{2}\right), \ldots, M\left(\mathbf{s}_{\mathrm{N}}\right)\right\}$ dan indeks parameter lokasi $\mathbf{s}_{\mathrm{i}}, i=1,2, \ldots, N$, maka $\left\{M(\mathbf{s}): \mathbf{s} \in \mathbb{R}^{3}\right\}$ disebut proses spasial. Proses spasial memiliki variabilitas, sehingga memerlukan hipotesis stasioner yang menjamin bahwa model yang diprediksi dari data sampel berlaku juga bagi data populasi. Daerah yang memenuhi asumsi stasioner dinamakan daerah stasioner. Ada tiga jenis kestasioneran proses spasial (Montero dkk, 2015, halaman 14-17) yaitu:

1. Proses spasial $\left\{M(\mathbf{s}): \mathbf{s} \in \mathbb{R}^{3}\right\}$ dikatakan stasioner kuat (strictlystationary) jika untuk sebarang indeks parameter lokasi $\mathbf{s}_{1}, \mathbf{s}_{2}, \ldots, \mathbf{s}_{\mathrm{N}}$ dan untuk sebarang translasi vektor $\mathbf{h} \in$ $\mathbb{R}^{3}$ berlaku:

$$
F_{\mathbf{s}}\left(M\left(\mathbf{s}_{2}\right), M\left(\mathbf{s}_{2}\right), \ldots, M\left(\mathbf{s}_{\mathrm{N}}\right)\right)=F_{\mathbf{s}+\mathbf{h}}\left(M\left(\mathbf{s}_{2}+\mathbf{h}\right), M\left(\mathbf{s}_{2}+\mathbf{h}\right), \ldots, M\left(\mathbf{s}_{\mathrm{N}}+\mathbf{h}\right)\right)
$$

dengan $F$ adalah fungsi distribusi gabungan, dan $\mathbf{s}_{\mathbf{i}} \in \mathbb{R}^{3}, i=1,2, \ldots, N$

2. Proses spasial $\left\{M(\mathbf{s}): \mathbf{s} \in \mathbb{R}^{3}\right\}$ dikatakan stasioner lemah (weaklystationary) atau stasioner orde dua (second-order stationary) jika memenuhi:

a. Rataan ada dan konstan, serta tidak bergantung pada lokasi yaitu:

$$
E[M(\mathbf{s})]=m(\mathbf{s})=m \text { untuk } \mathbf{s} \in \mathbb{R}^{3}
$$

b. Kovariansi ada untuk setiap pasangan $M(\mathbf{s})$ dan $M(\mathbf{s}+\mathbf{h})$ dan hanya bergantung pada vektor $\mathbf{h}$ yaitu:

$$
C(M(\mathbf{s}), M(\mathbf{s}+\mathbf{h}))=C(\mathbf{h}), \text { untuk } \mathbf{s} \in \mathbb{R}^{3}
$$

dengan $C(\mathbf{h})$ disebut fungsi kovariansi yang memenuhi $\operatorname{var}(M(\mathbf{s}))=C(\mathbf{0})=\sigma^{2}$

3. Proses spasial $\left\{M(\mathbf{s}): \mathbf{s} \in \mathbb{R}^{3}\right\}$ memenuhi stasioner intrinsik (intrinsically stationary) jika untuk sebarang translasi vektor $\mathbf{h}$ memenuhi kondisi:

$$
E[M(\mathbf{s}+\mathbf{h})-M(\mathbf{s})]=0
$$

dan

$$
\operatorname{var}(M(\mathbf{s}+\mathbf{h})-M(\mathbf{s}))=2 \gamma(\mathbf{h})
$$

dengan $2 \gamma(\mathbf{h})$ adalah variogram pada lag spasial $|\mathbf{h}|$ dan $\gamma(\mathbf{h})$ adalah semivariogram pada lag spasial $|\mathbf{h}|$.

Perhatikan pasangan observasi $M(\mathbf{s})$ dan $M(\mathbf{s}+\mathbf{h})$ pada Gambar II.1. Misalkan $\mathbf{s}_{1}=$ $\left\langle x_{1}, y_{1}, z_{1}\right\rangle$ dan $\mathbf{s}_{2}=\left\langle x_{2}, y_{2}, z_{2}\right\rangle$ untuk $\mathbf{s}_{1}, \mathbf{s}_{2} \in \mathbb{R}^{3}$, maka vektor hdidefinisikan sebagai:

$$
\mathbf{h}=\mathbf{s}_{\mathbf{2}}-\mathbf{s}_{1}=\left\langle x_{2}-x_{1}, y_{2}-y_{1}, z_{2}-z_{1}\right\rangle
$$

danpanjang vektor hdituliskan dengan $|\mathbf{h}|$, didefinisikan sebagai:

$$
|\mathbf{h}|=\sqrt{\left(x_{2}-x_{1}\right)^{2}+\left(y_{2}-y_{1}\right)^{2}+\left(z_{2}-z_{1}\right)^{2}}
$$




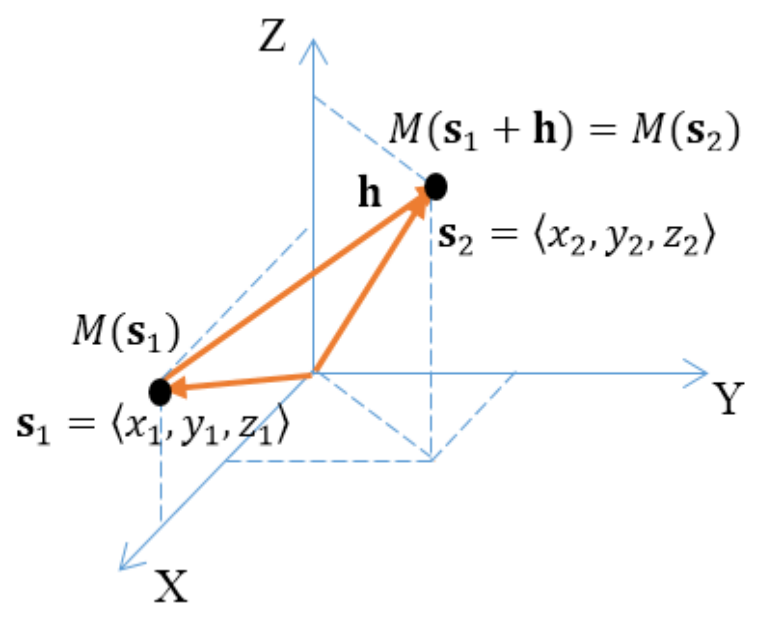

Gambar 1 Pasangan dua observasi yang dipisahkan oleh vektor $\mathbf{h}$ dalam tiga dimensi.

Dalam kasus stasioner orde dua, terdapat ekivalensi antara fungsi kovariansi dan semivariogram. Hubungan dua fungsi tersebut (Armstrong, 1998) dirumuskan dalam persamaan berikut:

$$
\begin{aligned}
2 \gamma(\mathbf{h}) & =\operatorname{var}(M(\mathbf{s}+\mathbf{h})-M(\mathbf{s})) \\
& =2 C(\mathbf{0})-2 C(\mathbf{h})
\end{aligned}
$$

dengan $2 \gamma(\mathbf{h})$ adalah variogram pada lag spasial $|\mathbf{h}|$ dan $\gamma(\mathbf{h})$ adalah semivariogram pada lag spasial $|\mathbf{h}|$. Semivariogram ini disebut juga semivariogram teoritis. Hubungan dua fungsi disebut dapat dituliskan sebagai berikut

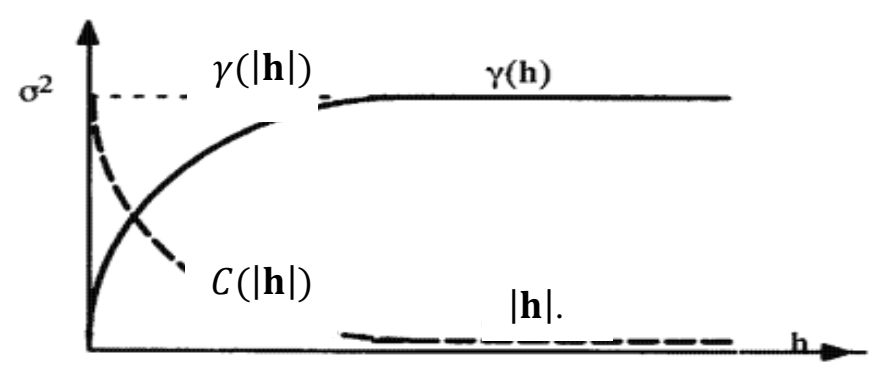

Gambar 2 Grafik fungsi kovariansi $C(|\mathbf{h}|)$ dan semivariogram $\gamma(|\mathbf{h}|)$. Fungsi kovariansi berbanding terbalik dengan fungsi semivariogram, jika $|\mathbf{h}|$ menuju tak hingga maka fungsi kovariansi konvergen ke nol sedangkan fungsi semivariogram konvergen ke sillyaitu $C(\mathbf{0})$.

Semivariogram dapat ditaksir oleh semivariogram eksperimental.Semivariogram eksperimental disebut juga dengan semivariogram empirik yaitu alat yang digunakan untuk mengukur korelasi spasial dalam variabel teregional (Montero, 2015). Semivariogram eksperimental didefinisikan sebagai:

$$
\hat{\gamma}(\mathbf{h})=\frac{1}{2 N(\mathbf{h})} \sum_{i=1}^{N(\mathbf{h})}\left(M\left(\mathbf{s}_{\mathrm{i}}+\mathbf{h}\right)-M\left(\mathbf{s}_{\mathrm{i}}\right)\right)^{2}
$$

dengan

$\mathbf{s}_{\mathrm{i}} \quad$ : indeks parameterlokasi ke $i$

$M\left(\mathbf{s}_{\mathrm{i}}\right) \quad$ : nilai observasi di lokasi $\mathbf{s}_{\mathrm{i}}$

$N(\mathbf{h}) \quad$ : banyaknya pasangan lokasi yang dipisahkan oleh jarak vektor $\mathbf{h}$

$\hat{\gamma}(\mathbf{h}) \quad$ : semivariogram eksperimental pada lag spasial $|\mathbf{h}|$ 
Model-model semivariogram dibagi dua jenis yaitu model stasioner dan model yang tidak stasioner (Kintanidis, 1997). Model semivariogram dikatakan stasioner jika $\lim _{|\mathbf{h}| \rightarrow \infty} \gamma(|\mathbf{h}|)=C(0)=\sigma^{2} \quad$ (nilai semivariogram terbatas pada variansi $\sigma^{2}$. Model semivariogram dikatakan tidak stasioner jika nilai semivariogram tidak terbatas untuk $|\mathbf{h}| \rightarrow \infty$. Dalam kasus ini, data spasia diasumsikan stasioner dengan model semivariogram digunakan yaitu:

1. Model Eksponensial

Model ini baik digunakan untuk data yang memiliki variansi yang kecil. Model Eksponensial berlaku di $\mathbb{R}^{d}, d>1$, dan dirumuskan sebagai:

$$
\gamma(|\mathbf{h}|)=C\left(1-\exp \left(-\frac{|\mathbf{h}|}{a}\right)\right)
$$

dengan practical range $\approx 3 a$. Model ini tidak banyak dijumpai dalam kasus pertambangan karena yang berhingga dihubungkan dengan suatu proses kontinu.

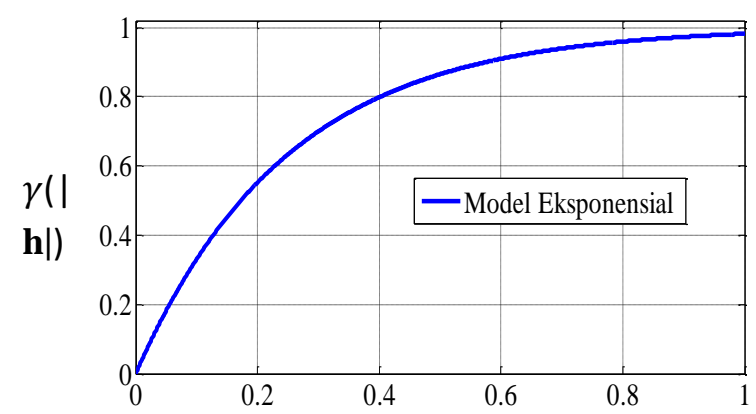

$|\mathbf{h}|$

Gambar 3 Model Eksponensial dengan $\operatorname{sill}(C)=1$ dan skala parameter $(a)=0,25$

2. Model Gauss

Model ini berlaku di $\mathbb{R}^{d}, d>1$, dan dirumuskan sebagai:

$$
\gamma(|\mathbf{h}|)=C\left(1-\exp \left(-\frac{|\mathbf{h}|^{2}}{a^{2}}\right)\right)
$$

dengan practical range $\approx a \sqrt{3}$. Model Gauss banyak digunakan dalam geostatistik perminyakan.

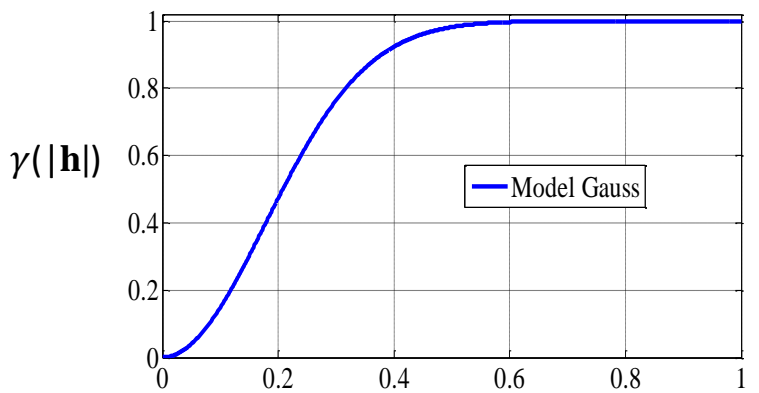

$|\mathbf{h}|$

Gambar 4 Model Gauss dengan $\operatorname{sill}(C)=1$ danskala parameter $(a)=0,25$

Semivariogram anisotropik merupakan semivariogram yang bergantung pada jarak vektor $\mathbf{h}$ dan memberikan nilai parameter yang berbeda pada tiap arah $\alpha$ dan $\beta$. Ada dua tipe semivariogram anisotropik yaitu anisotropik geometrik dan anisotropik zonal. Semivariogram anisotropik geometrik disebut juga dengan semivariogram anisotropik eliptikal. Pada kasus tiga dimensi, korelasi spasialnya dihitung dalam volume elipsoida. Semivariogram disebut anisotropik geometrik atau eliptikal jika pada semua arah sudut anisotropik dan range yang berbeda mempunyai nilai sill sama. Sedangkan semivariogram disebut anisotropik zonal jika 
semua arah sudut anisotropik dan sill yang berbeda mempunyai nilai range yang sama. Untuk pembahasan kali ini fokus pada semivariogram anisotropik geometrik.

Pada kasus tiga dimensi $\left(\mathbb{R}^{3}\right)$, struktur semivariogram anisotropik geometrik korespondesi dengan elipsoida. Ada lima parameter yang dibutuhkan dalam elipsoida yaitu: tiga range $\left(a_{x}, a_{y}, a_{z}\right)$ dan dua sudut rotasi $(\alpha, \beta)$ yang merupakan arah sumbu anisotropik. Misalkans $=\left\langle x_{i}, y_{i}, z_{i}\right\rangle \in \mathbb{R}^{3} i, j=1,2, \ldots, N$, maka diperoleh vektor $\mathbf{h}$

$$
\mathbf{h}=\left\langle x_{i}-x_{j}, y_{i}-y_{j}, z_{i}-z_{j}\right\rangle, \quad i, j=1,2, \ldots, N
$$

Pada Model semivariogram anisotropik,vektor $\mathbf{h}$ tersebut dilakukan transformasi yang berkaitan dengan korelasi spasial terhadap arah sudut anisotropik $(\alpha, \beta)$ dengan range masing-masing adalah $a_{x}$ pada arah Latitude, rangea ${ }_{y}$ pada arah Longitude dan rangea $_{z}$ pada arah Depth sehingga diperoleh

$$
\mathbf{h}^{*}=\left[\begin{array}{ccc}
\frac{1}{a_{x}} & 0 & 0 \\
0 & \frac{1}{a_{y}} & 0 \\
0 & 0 & \frac{1}{a_{z}}
\end{array}\right]\left[\begin{array}{ccc}
\cos \alpha \cos \beta & \sin \alpha \cos \beta & \sin \beta \\
-\sin \alpha & \cos \alpha & 0 \\
-\cos \alpha \sin \beta & -\sin \alpha \sin \beta & \cos \beta
\end{array}\right]\left[\begin{array}{l}
x_{i}-x_{j} \\
y_{i}-y_{j} \\
z_{i}-z_{j}
\end{array}\right]
$$

dan panjang vektor $\mathbf{h}^{*}$ dinyatakan sebagai:

$$
\left|\mathbf{h}^{*}\right|=\sqrt{\begin{array}{c}
\left(\frac{\left(\mathrm{x}_{\mathrm{i}}-\mathrm{x}_{\mathrm{j}}\right) \cos \alpha \cos \beta+\left(\mathrm{y}_{\mathrm{i}}-\mathrm{y}_{\mathrm{j}}\right) \sin \alpha \cos \beta+\left(\mathrm{z}_{\mathrm{i}}-z_{\mathrm{j}}\right) \sin \beta}{a_{x}}\right)^{2} \\
+\left(\frac{-\left(x_{\mathrm{i}}-x_{\mathrm{j}}\right) \sin \alpha+\left(\mathrm{y}_{\mathrm{i}}-\mathrm{y}_{\mathrm{j}}\right) \cos \alpha}{a_{y}}\right)^{2}+ \\
\left(\frac{-\left(x_{\mathrm{i}}-x_{\mathrm{j}}\right) \cos \alpha \sin \beta-\left(\mathrm{y}_{\mathrm{i}}-\mathrm{y}_{\mathrm{j}}\right) \sin \alpha \sin \beta+\left(z_{\mathrm{i}}-z_{\mathrm{j}}\right) \cos \beta}{a_{z}}\right)^{2}
\end{array}}
$$

untuk setiap $i, j=1,2, \ldots, N$.

Berdasarkan hal tersebut diperoleh model semivariogram anisotropik yang konsisten yang dikenal dengan isotropik ekivalen, $\gamma\left(\left|\mathbf{h}^{*}\right|\right)$. Misalkan model semivariogram yang dipilih adalah Eksponensial:

$$
\begin{aligned}
& \gamma\left(\left|\mathbf{h}^{*}\right|\right)
\end{aligned}
$$

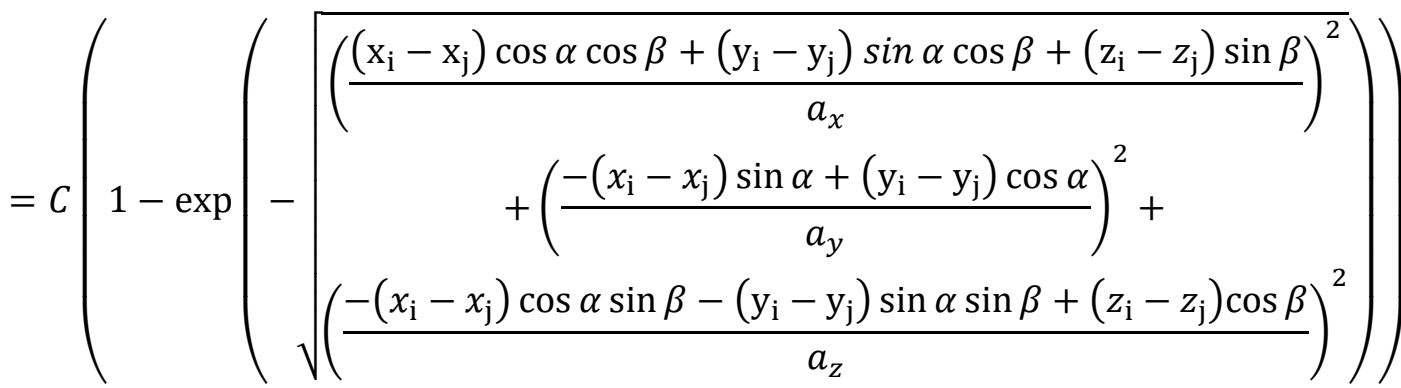

untuk setiap $i, j=1,2, \ldots, N$

Ordinary Kriging (OK) merupakan suatu metode kriging yang mendapatkan penaksir linear tak bias terbaik atau BLUE (Best Linear Unbiased Estimator). Misalkan $M=\{M(\mathbf{s}), \mathbf{s} \in$ $\mathbb{R}^{3}$ \}, fungsi acak stasioner orde dua dengan rataan $m$ konstan tetapi tidak diketahui dan fungsi 
kovariansi $C(\mathbf{h})$ yang diketahui. Untuk memprediksi nilai suatu lokasi $\mathbf{s}_{0}$ yaitu $\widehat{M}\left(\mathbf{s}_{0}\right)$ digunakan kombinasi linear dari $M\left(\mathbf{s}_{1}\right), M\left(\mathbf{s}_{2}\right), \ldots, M\left(\mathbf{s}_{\mathrm{N}}\right)$ (Montero dkk, 2015) yaitu:

$$
\widehat{M}\left(\mathbf{s}_{0}\right)=\sum_{i=1}^{N} \lambda_{i} M\left(\mathbf{s}_{\mathbf{i}}\right)
$$

dan variansi kriging diberikan oleh:

$$
\sigma_{e}^{2}=\sum_{i=1}^{N} \lambda_{i} \gamma\left(\mathbf{s}_{i}, \mathbf{s}_{0}\right)+\mu
$$

dengan $\lambda_{i}$ adalah bobot kriging dan $\mathbf{s}_{i}$ adalahindeks parameter lokasi ke- $i$ dengan $i=1,2, \ldots, N$

\section{METODE PENELITIAN}

Data yang digunakan dalam pemodelan variogram dan prediksi dengan metode kriging adalah data sumber gempayang diperoleh dari website IRIS (Incorporated Research Institutions For Seismology). Data kejadian gempa bumi historik yang pernah terjadi di wilayah Indonesia yaitu di Laut Banda, daerah Indonesia bagian Timur dengan katalog International Seismological Center (ISC). Data yang dipilih adalah data gempa pada tanggal 31 Januari 2008, dengan ukuran data kekuatan gempa bumi dinyatakan dengan magnitude dalam skala Richter (SR) dan dilambangkan dengan $\mathrm{M}$, dengan rata-rata kekuatan gempa berada lebih dari 2,5 $\mathrm{M}$, dan umumnya di atas skala ini dapat dirasakan dan bahkan menyebabkan kerusakan.Pada periode tersebut banyak terjadi gempa diakibatkan adanya perubahan cuaca dan aktivitas zona subduksi.

Analisis data gempa terdiri atas statistik deskriptif, semivariogram dan kriging. Statistik desktiptif digunakan mengambarkan tentang data, semivariogram digunakan untuk menggambarkan dan menjelaskan korelasi spasial antar observasi data, dan kriging bertujuan untuk mencari bobot setiap data observasi yang akan digunakan mengestimasi atau memprediksi suatu data observasi yang tidak tersampel melalui observasi data disekitarnya. Data gempa diasumsikan stasioner dengan metode kriging yang digunakan adalah Ordinary Kriging (OK).

\section{HASIL DAN PEMBAHASAN}

Data kekuatan gempa bumi diolah dalam arah sumbu koordinat tiga dimensi. Analisis semivariogram untuk setiap perhitungan arah sumbu anisotropik dibuat dalam 4 arah utama yaitu arah $0^{\circ}, 45^{\circ}, 90^{\circ}$, dan $135^{\circ}$. Dengan demikian, ada 21 arah sumbu anisotropik berbeda yang dianalisis dalam tiga dimensi. Hasil analisis semivariogram eksperimental, dan pencocokkan model semivariogram dalam arah sumbu anisotropik: berdasarkan Persamaan (2.2) dan Persamaan (2.3) sehingga diperoleh model sebagai berikut:

1. Arah sumbu mayor terpanjang (Depth) dengan range 0,4:

a. Model Eksponensial

$$
\gamma(|\mathbf{h}|)=0,5063\left(1-\exp \left(-\frac{|\mathbf{h}|}{0,4}\right)\right)
$$

b. Model Gauss

$$
\gamma(|\mathbf{h}|)=0,5063\left(1-\exp \left(-\left(\frac{|\mathbf{h}|}{0,4}\right)^{2}\right)\right)
$$

2. Arah sumbu mayor kedua (Longitude) dengan range 0,3:

a. Model Eksponensial

b. Model Gauss

$$
\gamma(|\mathbf{h}|)=0,5063\left(1-\exp \left(-\frac{|\mathbf{h}|}{0,3}\right)\right)
$$

$$
\gamma(|\mathbf{h}|)=0,5063\left(1-\exp \left(-\left(\frac{|\mathbf{h}|}{0,3}\right)^{2}\right)\right)
$$


3. Arah sumbu minor (Latitude) dengan range 0,1 :

a. Model Eksponensial

b. Model Gauss

$$
\gamma(|\mathbf{h}|)=0,5063\left(1-\exp \left(-\frac{|\mathbf{h}|}{0,1}\right)\right)
$$

$$
\gamma(|\mathbf{h}|)=0,5063\left(1-\exp \left(-\left(\frac{|\mathbf{h}|}{0,1}\right)^{2}\right)\right)
$$

Berdasarkan Persamaan (4) dan pencocokan model semivariogram anisotropik secara umum diperoleh model semivariogram Eksponensial dengan bentuk:

$$
\gamma\left(\left|\mathbf{h}^{*}\right|\right)=0,5063\left(1-\exp \left(-\left(\begin{array}{c}
\left(\frac{\left(x_{\mathrm{i}}-x_{\mathrm{j}}\right) \cos \alpha \cos \beta+\left(\mathrm{y}_{\mathrm{i}}-\mathrm{y}_{\mathrm{j}}\right) \sin \alpha \cos \beta+\left(z_{\mathrm{i}}-z_{\mathrm{j}}\right) \sin \beta}{0,1}\right)^{2} \\
+\left(\frac{-\left(x_{\mathrm{i}}-x_{\mathrm{j}}\right) \sin \alpha+\left(\mathrm{y}_{\mathrm{i}}-\mathrm{y}_{\mathrm{j}}\right) \cos \alpha}{0,3}\right)^{2}+ \\
0,4
\end{array}\right)\right)\right.
$$

Model semivariogram pada persamaan di atas merupakan model semivariogram isotropik ekivalen dari model semivariogram Eksponensial yang berlaku untuk semua arah sumbu anisotropik. Model semivariogram tersebutakan digunakan dalam analisis kriging.

Analisis Ordinary Kriging yang digunakan berdasarkan asumsi rataan konstan dan tidak diketahui melalui pencocokkan model semivariogram eksperimetntal sesuai, yaitu model ssemivariogram Eksponensial. Data gempa bumi dengan ukuran 52 lokasi digunakan dalam analisis Ordinary Kriging (OK) dari data asli yang berukuran 55 lokasi, sedangkan 3 lokasinya digunakan sebagai estimasi. Model analisis kriging digunakan semivariogram Eksponensial dengan range masing-masing sumbu anisotropik adalah 0,1 arah Latitude, 0,3 arah Longitude, dan 0,4 arah Depth (satuan dalam derajat), serta sudut anisotropic $\alpha=45^{\circ}$ dan $\beta=135^{\circ}$. Berdasarkan Persamaan (5) dan Persamaan (7) diperoleh hasil estimasipada plot berikut:
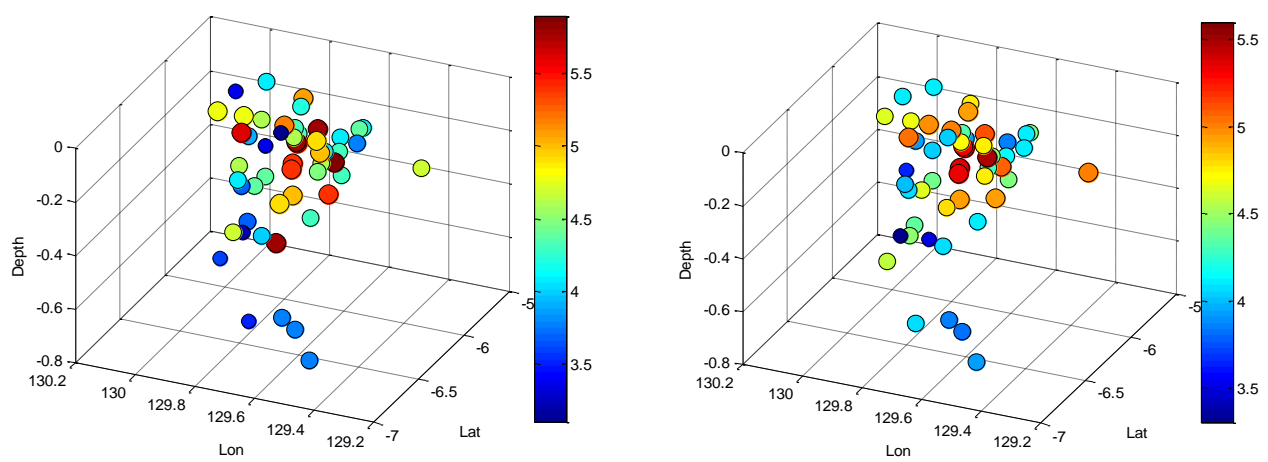

Gambar 5 Plot tiga dimensi (a) data asli kekuatan gempa bumi di 52 lokasi dan (b) hasil estimasi dengan metode OK. Warna pada plot tersebut menyatakan potensi kekuatan gempa. Dilihat dari warnanya, terdapat perbedaan potensi kekuatan gempa antara data asli dengan hasil estimasi.

Berdasarkan Gambar 5, hasil estimasi yang dianalisis dengan metode Ordinary Kriging (OK) satu persatu secara bergantian di 52 lokasi. Misalkan lokasi 1 yang akan diestimasi maka 
dalam analisis OK menggunakan 51 observasi disekitarnya. Jika lokasi 2 yang dianalisis, maka analisis krigingnya menggunakan lokasi 1 sampai 52 tanpa lokasi 2. Selanjutnya, warna pada plot menyatakan perbedaan kekuatan gempa bumi, warna biru menunjukkan potensi kekuatan gempa yang cukup rendah sedangkan warna merah menunjukkan kekuatan gempa yang cukup tinggi. Dari Gambar 4.1, juga terlihat bahwa ada beberapa perbedaan hasil estimasi OK dengan data aslinya, salah satu perbedaannya adalah data asli dengan kekuatan gempa berwarna merah sedangkan hasil estimasi menunjukkan kekuatan gempa berwarna biru muda pada lokasi yang sama. Untuk melihat lebih jauh perbedaan tersebut, maka hasil estimasi OK dan data aslinya dipetakan ke bidang Latitude-Longitude, Latitude-Depth, dan Longitude-Depth yaitu sebagai berikut:

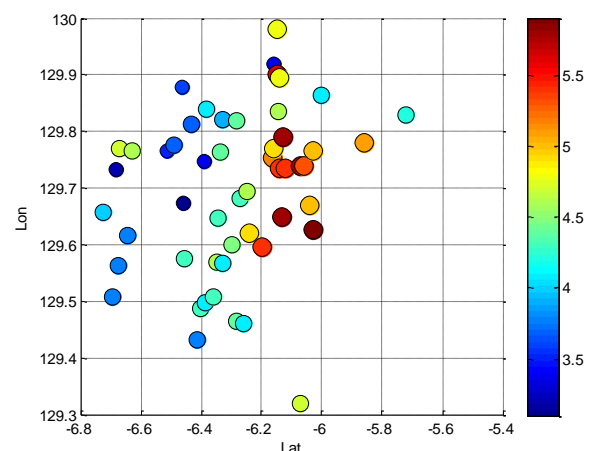

a(i)

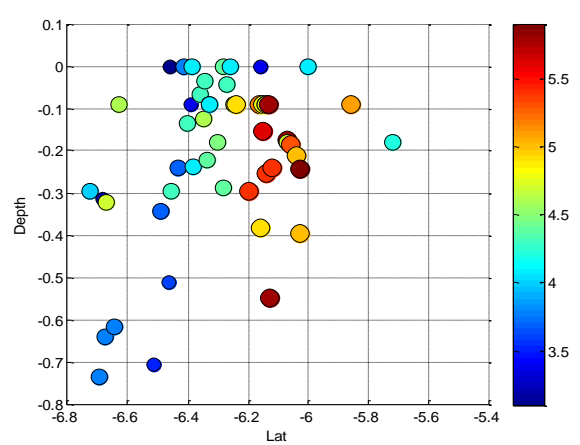

a(ii)

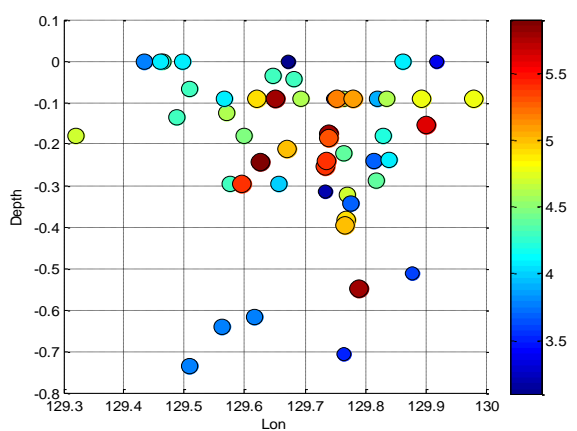

a(iii)

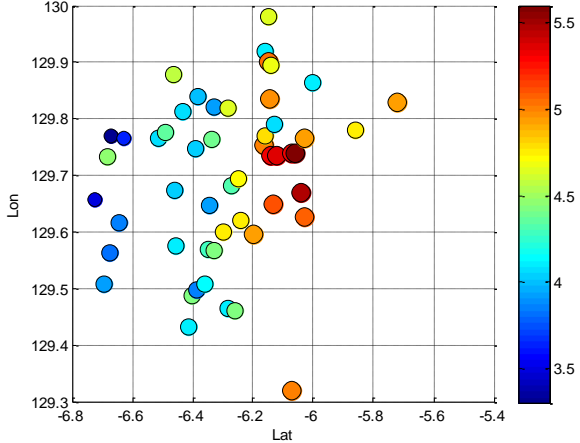

b(i)

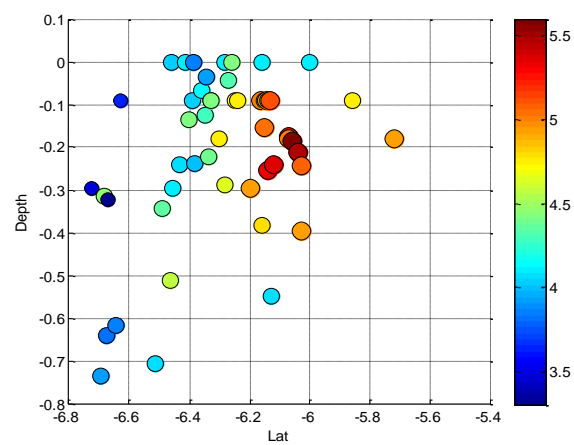

b(ii)

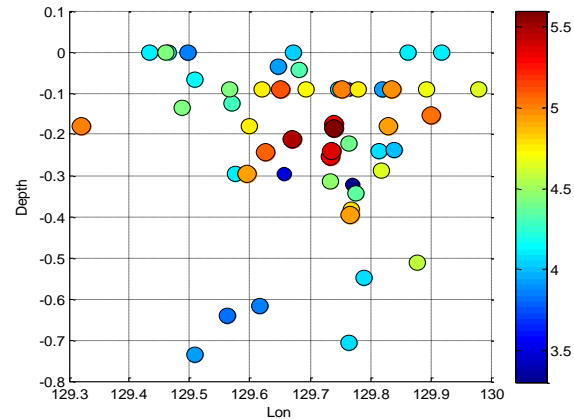

b(iii)

Gambar 6 Plot dua dimensi (a) data asli kekuatan gempa bumi di 52 lokasi dan (b) hasil estimasi dengan metode $\mathrm{OK}$.

Berdasarkan Gambar di atas terlihat bahwa ada beberapa hasil estimasi berbeda jauh dengan data aslinya. Perhatikan Gambar 4.2 (a(i) dan b(i)), terlihat bahwa pada Latitude: -5,8 
sampai -5,6 dan Longitude: 129,8 (satuan dalam derajat) sampai 129,9, menunjukkan perbedaan kekuatan gempa yaitu data asli dengan kekuatan berwarna biru muda sedangkan hasil estimasi OK menunjukkan warna orange. Selanjutnya, pada Gambar 5 (a(ii) dan b(ii)), terlihat bahwa pada kedalaman: -0,5 sampai -0,6 dan Latitude: -6,2 sampai -6 (satuan dalam derajat), juga menunjukkan perbedaan kekuatan gempa denganhasil estimasi pada lokasi tersebut yaitu4,2183 M kecil dari 5,8 M yang merupakan data aslinya. Hal inipadalokasi tersebut dipengaruhi oleh nilai observasi data gempa bumi disekitarnya dengan rata-rata kurang $4 \mathrm{M}$. Dari Gambar 4.2, juga terlihat bahwakekuatan gempa tertinggi dengan rataan lebih dari $5 \mathrm{M}$ berada pada Latitude: -6,2 sampai -6, Longitude: 199,6 sampai 199,8 dengan kedalaman: -0.1 sampai -0,3 (satuan dalam derajat). Hal ini menyebabkan hasil prediksi di sekitar lokasi tersebut akan lebih besar atau lebih kecil dari nilai aslinya dan mendekati nilai data observasi yang ada di sekitarnya. Untuk mengetahui lebih jauh mengenai hasil analisis kriging dilakukan perubahan besar sudut anisotropik seperti tabel berikut:

Tabel 1 Hasil estimasi kekuatan gempa pada tiga lokasi dengan beberapa besar sudut anisotropik yang berbeda.

\begin{tabular}{|c|c|c|c|c|c|}
\hline \multirow{2}{*}{ Lokasi } & \multicolumn{2}{|c|}{$\begin{array}{c}\text { Sudut } \\
\text { Anisotropik }\end{array}$} & \multirow[t]{2}{*}{ Data Real } & \multirow{2}{*}{$\begin{array}{c}\text { Hasil } \\
\text { Prediksi }\end{array}$} & \multirow[t]{2}{*}{ Variansi } \\
\hline & $\alpha$ & $\beta$ & & & \\
\hline \multirow{16}{*}{$(-6,6341 ; 129,6598 ;-0,5848)$} & \multirow{4}{*}{$0^{\circ}$} & $0^{\circ}$ & \multirow{16}{*}{3,8} & 3,8803 & 0,1529 \\
\hline & & $45^{\circ}$ & & 3,7724 & 0,2115 \\
\hline & & $90^{\circ}$ & & 3,9280 & 0,2410 \\
\hline & & $135^{\circ}$ & & 3,8267 & 0,1719 \\
\hline & \multirow{4}{*}{$45^{\circ}$} & $0^{\circ}$ & & 3,8263 & 0,2421 \\
\hline & & $45^{\circ}$ & & 3,7500 & 0,2563 \\
\hline & & $90^{\circ}$ & & 3,8975 & 0,2338 \\
\hline & & $135^{\circ}$ & & 3,8137 & 0,1237 \\
\hline & \multirow{4}{*}{$90^{\circ}$} & $0^{\circ}$ & & 3,7974 & 0,2580 \\
\hline & & $45^{\circ}$ & & 3,8214 & 0,2803 \\
\hline & & $90^{\circ}$ & & 3,8693 & 0,2353 \\
\hline & & $135^{\circ}$ & & 3,8508 & 0,1379 \\
\hline & \multirow{4}{*}{$135^{\circ}$} & $0^{\circ}$ & & 3,7200 & 0,1891 \\
\hline & & $45^{\circ}$ & & 3,8908 & 0,2638 \\
\hline & & $90^{\circ}$ & & 3,8830 & 0,2423 \\
\hline & & $135^{\circ}$ & & 3,8150 & 0,1375 \\
\hline \multirow{5}{*}{$(-6,2385 ; 129,7207 ;-0,1895)$} & \multirow{4}{*}{$0^{\circ}$} & $0^{\circ}$ & \multirow{5}{*}{5,2} & 4,7814 & 0,1735 \\
\hline & & $45^{\circ}$ & & 4,6499 & 0,1746 \\
\hline & & $90^{\circ}$ & & 4,9445 & 0,1759 \\
\hline & & $135^{\circ}$ & & 5,0525 & 0,1796 \\
\hline & $45^{\circ}$ & $0^{\circ}$ & & 4,8486 & 0,1788 \\
\hline
\end{tabular}


https://jurnal.unsulbar.ac.id/index.php/saintifik

\begin{tabular}{|c|c|c|c|c|c|}
\hline & & $45^{\circ}$ & & 4,7561 & 0,1644 \\
\hline & & $90^{\circ}$ & & 4,9456 & 0,1732 \\
\hline & & $135^{\circ}$ & & 4,9643 & 0,1647 \\
\hline & \multirow{4}{*}{$90^{\circ}$} & $0^{\circ}$ & & 4,8087 & 0,1665 \\
\hline & & $45^{\circ}$ & & 4,9266 & 0,1476 \\
\hline & & $90^{\circ}$ & & 4,9313 & 0,1824 \\
\hline & & $135^{\circ}$ & & 4,8464 & 0,1798 \\
\hline \multirow{6}{*}{ Lokasi } & \multicolumn{2}{|c|}{$\begin{array}{c}\text { Sudut } \\
\text { Anisotropik }\end{array}$} & \multirow{2}{*}{ Data Real } & \multirow{2}{*}{$\begin{array}{c}\text { Hasil } \\
\text { Prediksi }\end{array}$} & \multirow{2}{*}{ Varians } \\
\hline & $\alpha$ & $\beta$ & & & \\
\hline & \multirow{4}{*}{$135^{\circ}$} & $0^{\circ}$ & & 4,7722 & 0,1695 \\
\hline & & $45^{\circ}$ & & 4,9799 & 0,1619 \\
\hline & & $90^{\circ}$ & & 4,9174 & 0,1869 \\
\hline & & $135^{\circ}$ & & 4,7896 & 0,1651 \\
\hline \multirow{12}{*}{$(-5,9500 ; 129,8000 ;-0,0898)$} & \multirow{4}{*}{$0^{\circ}$} & $0^{\circ}$ & \multirow{12}{*}{5} & 4,6130 & 0,3000 \\
\hline & & $45^{\circ}$ & & 4,3834 & 0,2574 \\
\hline & & $90^{\circ}$ & & 5,1482 & 0,1482 \\
\hline & & $135^{\circ}$ & & 5,1041 & 0,2369 \\
\hline & & $0^{\circ}$ & & 4,5854 & 0,2146 \\
\hline & 150 & $45^{\circ}$ & & 4,7413 & 0,2487 \\
\hline & 45 & $90^{\circ}$ & & 5,2029 & 0,1732 \\
\hline & & $135^{\circ}$ & & 5,0799 & 0,1978 \\
\hline & & $0^{\circ}$ & & 4,8998 & 0,2021 \\
\hline & 000 & $45^{\circ}$ & & 5,0757 & 0,2032 \\
\hline & 90 & $90^{\circ}$ & & 5,1390 & 0,1856 \\
\hline & & $135^{\circ}$ & & 4,8292 & 0,1600 \\
\hline
\end{tabular}

Berdasarkan di atas hasil estimasi dengan metode Ordinary Kriging (OK) untuk tiga lokasi menunjukkan nilai rata-rata niali estimasi cukup dekat dekat dengan dengan data aslinya.. Hal ini memberikan kesimpulan bahwa model semivariogram Ekspoenensial cukup baik dalam pengestimasian dan pemberian gambaran spasial di sekitar observasi pada data gempa.

\section{KESIMPULAN}

Berdasarkan hasil dan pembahasan dapat diambil kesimpulan bahwa model semivariogram Eksponensial.cukup baik untuk menggambarkan konfigurasi spasial dari potensi kekuatan gempa bumi di laut Banda melalui metode Ordinary Kriging yaitu: model 
semivariogram Eksponensial dengan range 0,1 (dalam derajat) pada sumbu anisotropik Latitude, range 0,3 (dalam derajat) pada sumbu anisotropik Longitude, dan dengan range 0,4 (dalam derajat) pada sumbu anisotropik Depth, serta memiliki sill 0,5063 (dalam derajat) yang korespondensi dengan elipsoida.Hal ini dikatakan model semivariogram memiliki keberpengaruhan spasial dalam volume elipsoida. Model semivariogram Eksponensial untuk data kekuatan gempa bumi dengan arah sudut anisotropik $(\alpha, \beta)$ adalah:

$$
\gamma\left(\left|\mathbf{h}^{*}\right|\right)=0,5063\left(1-\exp \left(-\left|\mathbf{h}^{*}\right|\right)\right)
$$

dengan:

$$
\left|\mathbf{h}^{*}\right|=\sqrt{\begin{array}{c}
\left(\frac{\left(\mathrm{x}_{\mathrm{i}}-\mathrm{x}_{\mathrm{j}}\right) \cos \alpha \cos \beta+\left(\mathrm{y}_{\mathrm{i}}-\mathrm{y}_{\mathrm{j}}\right) \sin \alpha \cos \beta+\left(\mathrm{z}_{\mathrm{i}}-z_{\mathrm{j}}\right) \sin \beta}{0,1}\right)^{2} \\
+\left(\frac{-\left(x_{\mathrm{i}}-x_{\mathrm{j}}\right) \sin \alpha+\left(\mathrm{y}_{\mathrm{i}}-\mathrm{y}_{\mathrm{j}}\right) \cos \alpha}{0,3}\right)^{2}+ \\
\left(\frac{-\left(x_{\mathrm{i}}-x_{\mathrm{j}}\right) \cos \alpha \sin \beta-\left(\mathrm{y}_{\mathrm{i}}-\mathrm{y}_{\mathrm{j}}\right) \sin \alpha \sin \beta+\left(z_{\mathrm{i}}-z_{\mathrm{j}}\right) \cos \beta}{0,4}\right)^{2}
\end{array}}
$$

\section{DAFTAR PUSTAKA}

Amnipoor, H., Ghafoori, M., Lashkaripour, Gholam Reza (2013): The Application of Geostatistical Method to Repair the 3D Petrophysical Model of Oil Reservoir, Open Journal of Geology,3,7-18.

Armstrong, Margaret (1998): Basic Linear Geostatistics, Springer-Verlag, Heidelberg, New York.

Badan Meteorologi, Klimatologi, dan Geofisika mengenai gempa bumi, diperoleh melalui internet: http://www.bmkg.go.id/BMKG_Pusat/Gempabumi___Tsunami/Gempabumi.bmkg/. Diunduh pada tanggal Maret 2016

Banerjee, S.,Carlin, Bradley P., dan Gerfand, Alan E.. S. (1998): Hierarchical Modeling and Analysis for Spatial Data, Springer-Verlag, Heidelberg, New York.

Blackwell, M.R.L., (1972): A model of Bougainville copper's Panguna Orebody, In: D.G. Salamon and F.H. Lancaster (Editors), Application of Computer Methods in theMineral Industry. S.A.I.M.M., pp. 35-40.

Cressie, N.A.C. (1993): Statisticsfor Spatial Data, John Wiley and Sonc,Ins., New York.

David, Michel (1977): Geostatistical Ore Reserve Estimation, Amsterdam Oxford, New York.

Faisal, F. (2004): Estimasi Cadangan Emas dengan Sequential Kriging, Institut Teknologi Bandung.

Hohn, M. Edward (1999): Geostatistics and Petroleum Geology, 2nd, Kluwer Academic Publishers, London. 
https://jurnal.unsulbar.ac.id/index.php/saintifik

Isaaks Edward H. dan Srivastava R. Mohan (1989): Applied Geostatistics, Oxford Univessity Press, New York.

Kitanidis, P. K. (1997): Introduction to Geostatistics: Applications to Hydrogeology, CambridgeUniversity Press.

Kementerian Lingkungan Hidup (2013): Deskripsi Peta Ekoregional Laut Indonesia, Deputi Tata Lingkungan, Jakarta Indonesia.

Mcquire, Bill (2012): Waking the Giant: How a Changing Climate Triggers Earthquakes, Tsunamis, and Volcanoes, OxfordUniversity Press, New York.

Montero, Jose-Maria dkk (2015): Spatial and Spatio-Temporal Geostatistical Modeling and Kriging, John Wiley and Sons, Ltd.

Sari, RR. Kurnia Novita (2009): Model semivariogram dan Estimasi Ordinary Kriging untuk Nilai Ujian Nasional SMP di Kota Bandung dan Cimahi, Institut Teknologi Bandung.

Stein, Michael L. (1999): .Interpolasi Of Spatial Data, Springer-Verlag,New York.

Tim Revisi Peta Gempa Indonesia (2010): Ringkasan Hasil Studi Tim Revisi Peta Gempa Indonesia 2010, Bandung.

Wackernagel,Hans (1995):Multivariate Geostatistics andAnalysis forSpatial Data,SpringerVerlag,Heidelberg,New York. 